\title{
Fusion of the Genes PHF1 and TFE3 in Malignant Chondroid Syringoma
}

\author{
IOANNIS PANAGOPOULOS ${ }^{1}$, LUDMILA GORUNOVA ${ }^{1}$, \\ MARIUS LUND-IVERSEN ${ }^{2}$, ASSIA BASSAROVA ${ }^{2}$ and SVERRE HEIM ${ }^{1,3}$ \\ ${ }^{1}$ Section for Cancer Cytogenetics, Institute for Cancer Genetics and Informatics, \\ The Norwegian Radium Hospital, Oslo University Hospital, Oslo, Norway; \\ ${ }^{2}$ Department of Pathology, Oslo University Hospital, Oslo, Norway; \\ ${ }^{3}$ Institute of Clinical Medicine, Faculty of Medicine, University of Oslo, Oslo, Norway
}

\begin{abstract}
Background/Aim: Malignant chondroid syringoma is a rare tumor of unknown pathogenesis. Materials and Methods: Genetic analyses were performed on a malignant chondroid syringoma. Results: G-banding analysis of shortterm cultured tumor cells yielded the karyotype 46,Y,t(X;6)(p11;p21)[15]/46,XY[2]. RNA sequencing detected an in-frame fusion of PHF 1 from $6 p 21$ with TFE3 from Xp11, verified by RT-PCR and Sanger sequencing. Genomic PCR showed that the PHF1-TFE3 junction was identical to the fusion found by RNA sequencing and RT-PCR. Conclusion: Malignant chondroid syringoma is genetically related to tumors with PHF1 rearrangements such as low-grade endometrial sarcoma and ossifying fibromyxoid tumor, but also with tumors having TFE3 rearrangements such as renal cell carcinoma, alveolar soft part sarcoma, PEComa, and epithelioid hemangioendothelioma. Further investigations on malignant chondroid syringomas are needed in order to determine whether genetic heterogeneity exists among them and the clinical impact of the PHF1-TFE3 fusion.
\end{abstract}

Malignant chondroid syringoma, also known as malignant mixed tumor of the skin, is a very rare tumor with less than 50 cases being described in the relevant literature. It is considered to be the malignant counterpart of benign chondroid syringoma (benign mixed tumor) $(1,2)$. Malignant chondroid syringomas are twice as common in women as in

This article is freely accessible online.

Correspondence to: Ioannis Panagopoulos, Section for Cancer Cytogenetics, Institute for Cancer Genetics and Informatics, The Norwegian Radium Hospital, Oslo University Hospital, Montebello, PO Box 4954 Nydalen, NO-0424 Oslo, Norway. Tel: +47 22782362, e-mail: ioannis.panagopoulos@rr-research.no

Key Words: Malignant chondroid syringoma, PHF1, TFE3, PHF1TFE3 fusion gene, RNA sequencing. men and show predilection for the trunk and extremities (13 ). The clinical course is unpredictable (4). Half of the reported cases had local recurrences whereas nodal and distant metastases were observed in $39 \%$ and $36 \%$ of the cases, respectively. The most common sites for distant metastases are the lungs, bone, and brain (4). Malignant chondroid syringoma is composed of both epithelial and mesenchymal tissue. The epithelial component consists of neoplastic cells with hyperchromatic nuclei and abundant mitotic figures, with occasional areas of necrosis. The mesenchymal component may show myxoid, chondroid, osteoid, adipose or fibrous features enclosing clusters of epithelial cells (1-3).

Malignant and benign chondroid syringomas are cutaneous myoepithelial neoplasms (5-9). Genetic studies of both cutaneous and soft tissue myoepithelial neoplasms have demonstrated considerable genetic heterogeneity (10-14). In some of these tumors, EWSR1-ZNF444, EWSR1-PBX1, EWSR1-PBX3 or EWSR1-POU5F1 fusion genes have been found $(10,12,13,15)$ whereas others had rearrangements of PLAG1 $(11,14)$. The differential diagnosis for myoepithelial tumor is extremely broad and may include ossifying fibromyxoid tumors $(7,16)$. In the latter, the PHD finger protein 1 gene $(P H F 1)$ is recurrently rearranged (17) with an EP400-PHF 1 fusion being detected in some tumors $(17,18)$.

Herein, we present a malignant chondroid syringoma which had a $\mathrm{t}(\mathrm{X} ; 6)(\mathrm{p} 11 ; \mathrm{p} 21)$ as the sole karyotypic aberration. Using RNA sequencing and molecular methodologies, we demonstrated that the molecular consequence of the translocation was the fusion of the PHF 1 gene from 6p21 with the transcription factor binding to IGHM enhancer 3 gene (TFE3) from Xp11.

\section{Materials and Methods}

Ethics statement. The study was approved by the regional Ethics Committee (Regional komité for medisinsk forskningsetikk Sør-Øst, Norge, http://helseforskning.etikkom.no). Written informed consent was obtained from the patient for publication of the case details. 
Table I. Primers used for PCR amplification and Sanger sequencing analyses.

\begin{tabular}{|c|c|c|c|c|}
\hline Name & Sequence $\left(5^{\prime}->3^{\prime}\right)$ & Position & Reference sequence & Gene \\
\hline PHF1-1295F1 & CTGGGGGAGGGGTCTCACGTCC & $1295-1316$ & NM_002636.4 & PHFl \\
\hline TFE3-1431R1 & GGTGCCCTTGTTCCAGCGCATC & $1452-1431$ & NM_006521.5 & TFE3 \\
\hline PHF1-Intr11-F2 & AGGTCTTGGGGGTGTCCGGGAGG & $33414902-33414924$ & NC_0̄00006.12 & PHF1 \\
\hline TFE3-Intr7-R2 & GTGCTGTGCAGGCCTGCCTCACC & $49033696-49033674$ & NC_000023.11 & TFE3 \\
\hline PHF1-Intr11-F3 & GGCTGGGGGGATAAGGAGGCCTCT & $33414926-33414949$ & NC_000006.12 & PHF1 \\
\hline TFE3-Intr7-R3 & GGGCAATGCACACGCTCTCTGGC & $49033699-49033721$ & NC_000023.11 & TFE3 \\
\hline
\end{tabular}

The ethics committee's approval included a review of the consent procedure. All patient information has been de-identified.

Case description. A 61 year old male had noticed a tender, growing lump in the left deltopectoral fold, during the last 6 months. MRI revealed a subcutaneous heterogeneous tumor whose appearance evoked suspicion of a soft tissue sarcoma. On macroscopic examination following surgery, the tumor was partly chondroid with myxoid and necrotic areas. Viable tumor tissue was removed for culturing prior to formalin fixation. Microscopically, the tumor was composed of chondroid areas, spindle cells, epithelioid cells, and necrotic areas (Figure 1A). The tumor cells were positive for cytokeratins and also weakly for S-100. The tumor was classified as a malignant chondroid syringoma. Because of the molecular findings (see below), immunohistochemistry was performed using TFE3 (MRQ-37) rabbit monoclonal antibody (Cell Marque, CA, USA) according to the company's recommendations. The TFE3 antibody showed strong nuclear positivity (Figure 1B).

G-banding and karyotyping. Fresh tissue from a representative area of the tumor was short-term cultured and analyzed cytogenetically as previously described (19).

$R N A$ sequencing. Total RNA was extracted from frozen $\left(-80^{\circ} \mathrm{C}\right)$ tumor tissue adjacent to that used for cytogenetic analysis and histologic examination using miRNeasy Mini Kit (Qiagen Nordic, Oslo, Norway). One $\mu \mathrm{g}$ of total RNA was sent to the Genomics Core Facility at the Norwegian Radium Hospital, Oslo University Hospital (http://genomics.no/oslo/) for high-throughput paired-end RNA-sequencing using the Illumina TruSeq Stranded mRNA protocol. The software FusionCatcher $(20,21)$ was used to find fusion transcripts.

Reverse transcription (RT) and genomic PCR analyses. The primers used for PCR amplifications and Sanger sequencing analyses are shown in Table I. One $\mu \mathrm{g}$ of total RNA was reverse-transcribed in a $20 \mu \mathrm{l}$ reaction volume using iScript Advanced cDNA Synthesis Kit for RT-qPCR according to the manufacturer's instructions (BioRad, Oslo, Norway). Genomic DNA was extracted using the Maxwell RSC Instrument and the Maxwell RSC Tissue DNA Kit (Promega, Madison, WI, USA) and the concentration was measured using the Quantus Fluorometer and the QuantiFluor ONE dsDNA System (Promega).

For amplification of the PHF1-TFE3 fusion transcript, the primers used were the forward PHF1-1295F1 and the reverse TFE31431R1. For amplification of genomic PHF1-TFE3 fragments, the primer combinations were PHF1-Intr11-F2/TFE3-Intr7-R2 and
PHF1-Intr11-F3/TFE3-Intr7-R3. All PCR amplifications were performed in $25 \mu \mathrm{l}$ reaction volume which contained 12.5 $\mu$ l Premix Ex Taq $^{\mathrm{TM}}$ DNA Polymerase Hot Start Version (Takara Bio Europe/SAS, Saint-Germain-en-Laye, France), template (1 $\mu \mathrm{l} \mathrm{cDNA}$ or $100 \mathrm{ng}$ of genomic DNA), and $0.4 \mu \mathrm{M}$ of each of the forward and reverse primers. PCR amplifications were run on a C-1000 Thermal cycler (Bio-Rad) and the cycling was performed at $94^{\circ} \mathrm{C}$ for $30 \mathrm{sec}$ followed by 35 cycles of $7 \mathrm{sec}$ at $98^{\circ} \mathrm{C}, 30 \mathrm{sec}$ at $68^{\circ} \mathrm{C}$, $30 \mathrm{sec}$ at $72^{\circ} \mathrm{C}$, and a final extension for $5 \mathrm{~min}$ at $72^{\circ} \mathrm{C}$. Three $\mu \mathrm{l}$ of the PCR products were stained with GelRed (Biotium, VWR International, Oslo, Norway), analyzed by electrophoresis through $1.0 \%$ agarose gel, and photographed. The remaining PCR products were purified using the MinElute PCR Purification Kit (Qiagen) and direct sequenced using the dideoxy procedure with the BigDye terminator v1.1 cycle sequencing kit (ThermoFisher Scientific, Waltman, MA, USA) on the Applied Biosystems Model 3500 Genetic Analyzer sequencing system. The BLAST software (http://blast.ncbi.nlm.nih.gov/Blast.cgi) was used for computer analysis of sequence data.

\section{Results}

G-banding. The G-banding analysis yielded a karyotype with a single chromosome abnormality: $46, \mathrm{Y}, \mathrm{t}(\mathrm{X} ; 6)(\mathrm{p} 11 ; \mathrm{p} 21)$ [15]/46,XY[2] (Figure 2).

RNA sequencing and molecular genetic confirmation of the PHF1-TFE3 fusion. Using the FusionCatcher software with the fastq files from the RNA sequencing, a fusion of $P H F 1$ from 6p21 with TFE3 from Xp11 was found: GGAAAGT GGAGGAGCTGGGGCCACCCTCAGCAGTGCGCAATC AGCCCGAG*CAGAGACCGAGGCAAAGGCCCTTTTGA AGGAACGGCAGAAGAAAGACAAT.

RT-PCR with the primer combination PHF1-1295F1/TFE31431R1 amplified strongly a 286 bp cDNA fragment and weakly two other fragments of larger sizes, which were not further studied (Figure 3A). Direct sequencing of the $286 \mathrm{bp}$ PCR fragment showed that it was a PHF1-TFE3 chimeric cDNA fragment. The fusion point was identical to that found by analysis of the RNA sequencing data using the FusionCatcher software. Thus, in the PHF 1-TFE3 chimeric transcript, exon 12 of PHF1 (nt 1420 in sequence with accession number NM_002636.4) was fused in frame to exon 7 of TFE3 (nt 1135 in NM_006521.5) (Figure 3B). Two extra 
A

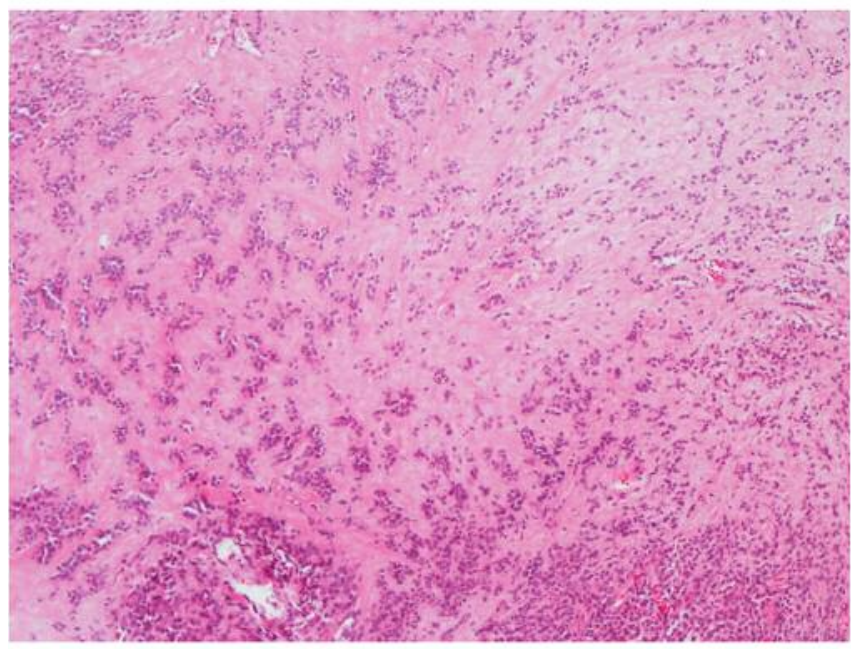

B

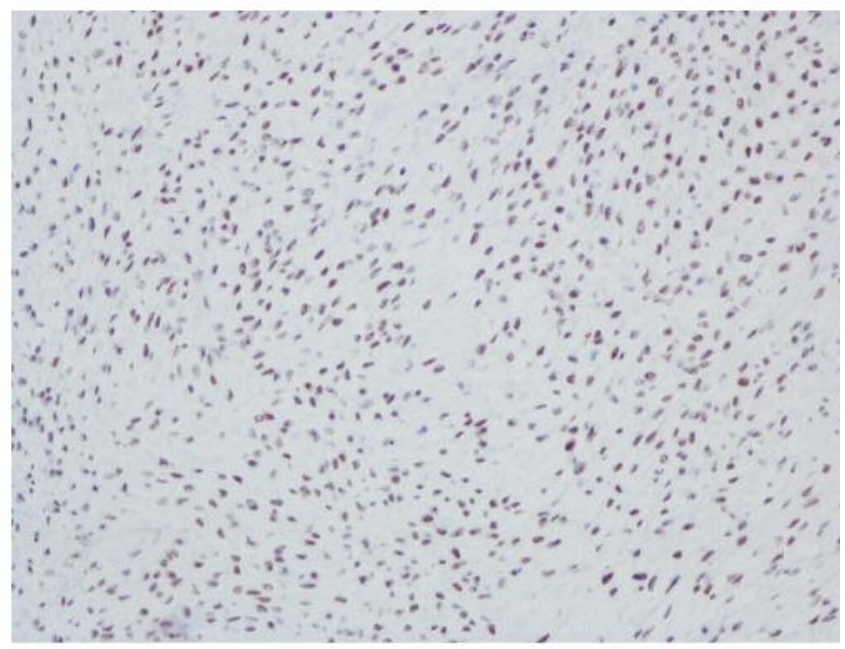

Figure 1. Microscopic examination of the malignant chondroid syringoma. A) H\&E-stained section showing tumor cells with epithelioid/myoepithelioid features embedded in hyaline stroma, 100x. B) Immunoexpression of TFE3 showing strong nuclear positivity, 200x.

nt "AG" were found at the junction maintaining the open reading frame. They most probably came from the acceptor/donor splicing site of intron 6/exon 7 of TFE3 (Ensemble; ENSG00000068323; ENST00000315869.7).

Genomic PCR with PHF1-Intr11-F2/TFE3-Intr7-R2 and PHF1-Intr11-F3/TFE3-Intr7-R3 amplified a 308 bp fragment and a 259 bp fragment, respectively (Figure 3C). Direct sequencing of the PCR products showed that they were genomic $P H F 1-T F E 3$ chimeric fragments and that the genomic $P H F 1-T F E 3$ junction was identical to the fusion point found by RNA sequencing and RT-PCR (Figure 3A-C).

\section{Discussion}

We identified a PHF1-TFE3 fusion gene in the cells of a malignant chondroid syringoma. To the best of our knowledge, this is the first time an acquired genetic change, let alone a fusion gene, is described in this type of tumor.

PHF1 encodes a polycomb group (PcG) protein that contains a tudor domain, PHD zinc finger domains, and a polycomb-like MTF2 factor 2 domain (22). PcG proteins are thought to form a multimeric complex that modifies local chromatin structure and establishes a heritable repression state at the particular loci. The PHF1 protein is a component of the histone H3 lysine-27 (H3K27) specific methyltransferase complex and is important for Hox gene expression in vivo (23, 24). PHF1 is also recruited to DNA double strand breaks and interacts physically with many proteins which are involved in DNA damage response (25). Recently, PHF1 was found to be a reader for histone H4R3 symmetric demethylation and to interact with the PRMT5-WDR77/CRL4B complex (26).

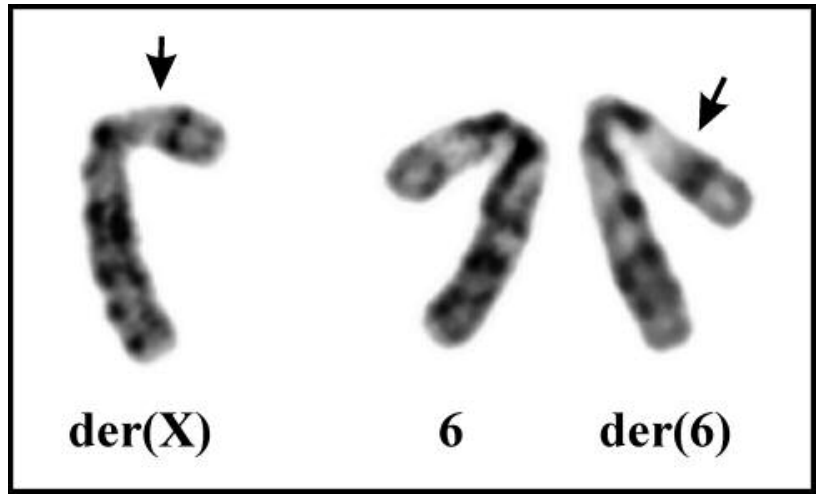

Figure 2. Cytogenetic analysis of the malignant chondroid syringoma. Partial karyotype showing the $\operatorname{der}(X) t(X ; 6)(p 11 ; p 21), \operatorname{der}(6) t(X ; 6)$ (p11;p21), and the normal chromosome 6. Breakpoint positions are indicated by arrows.

PHF 1 was first reported as a neoplasia-associated fusion partner in low-grade endometrial stromal sarcomas in which rearrangements of the chromosomal band $6 \mathrm{p} 21$ generated the JAZF1-PHF1 and EPC1-PHF1 fusion genes (27). Furthermore, MEAF6-PHF1, BRD8-PHF1, and EPC2-PHF 1 fusions have been reported in low-grade endometrial stromal sarcomas (28-31). Recurrent rearrangement of the $P H F 1$ gene and the fusion genes EP400-PHF1, EPC1-PHF1, and $M E A F 6-P H F 1$ have also been reported in ossifying fibromyxoid tumors $(17,18,32)$ and a $J A Z F 1-P H F 1$ and an AFF3-PHF1 fusion gene have been reported in an unusual ossifying sarcoma of the heart and a myxofibrosarcoma, 


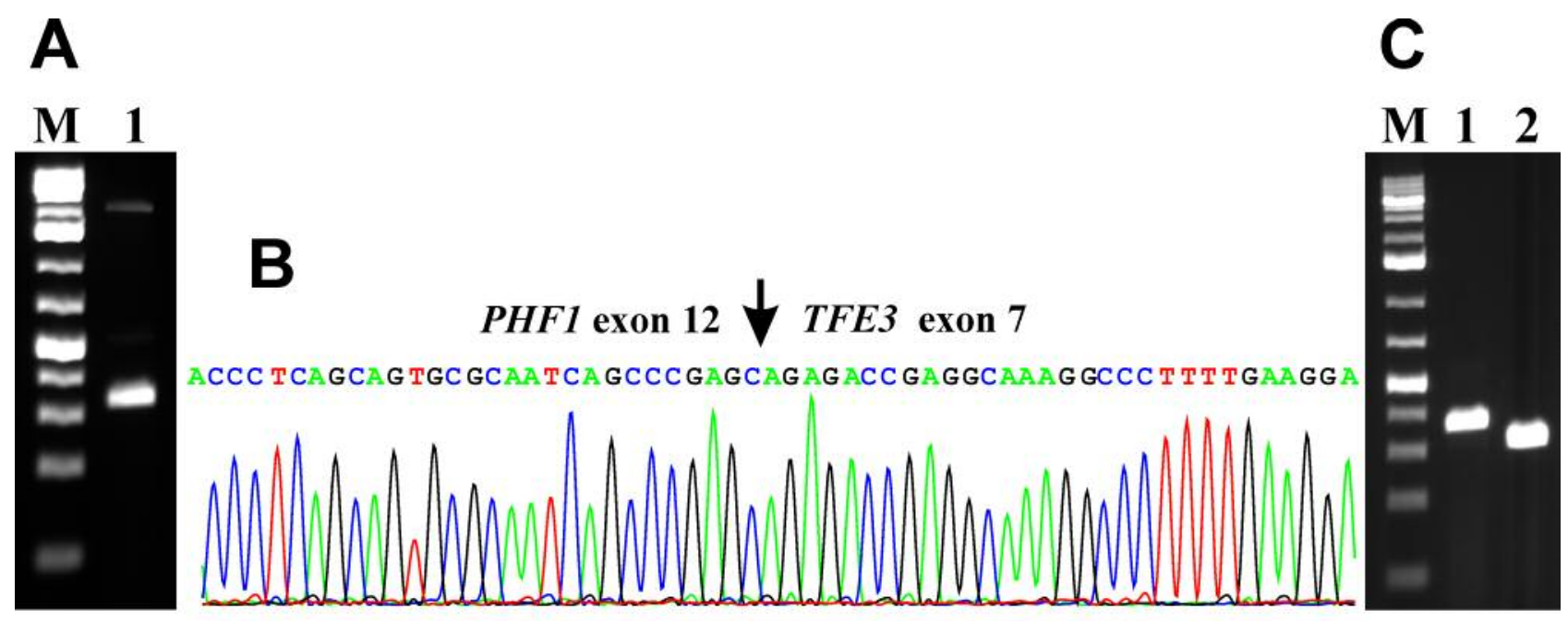

D

MAQPPRLSRSGASSLWDPASPAPTSGPRPRLWEGQDVLARWTDGLLYLGT
IKKVDSAREVCLVQFEDD SQF'LLWKDISPAALPGEELLCCVCRSETVVP
GNRLVSCEKCRHAYHQDCHVPRAPAPGEGEGTSWVCRQCVFAIATKRGGA
LKKGPYARAMLGMKLSLPYGLKGLDWDAGHLSNRQQSYCYCGGPGEWNLK
MLQCRSCLQWFHEACTQCLSKPLLYGDRFYEFECVCRGGPEKVRRLQLR
WVDVAHLVLYHLSVCCKKKYFDFDREILPFTSENWDSLLLGELSDTPKGE
RSSKLLSALNSHKDRFISGREIKKRKCLFGLHARMPPPVEPPTGDGALTR
AGPWGRGLTSPGEAPEAGARAPEEEAEGESGGAGATLSSAQSAR TEAK
ALLKERQKKDNHNLIERRRRFNINDRIKELGTLIPKSSDPEMRWNKGTI
KASVDYIRKLQKEQQRSKDLESRQRSLEQANRSLQLRIQELELQAQIHGL
PVPPTPGLLSLATTSASDSLKPEQLDIEEEGRPGAATFHVGGGPAQNAPH
QQPPAPPSDALLDLHFPSDHLGDLGDPFHLGLEDILMEEEEGVVGGLSGG
ALSPLRAASDPLLSSVSPAVSKASSRRSSFSMEEES

Figure 3. Molecular genetic analysis of the malignant chondroid syringoma. A) Gel electrophoresis showing the amplified cDNA fragment using the PHF1-1295F1/TFE3-1431R1 primer combination (lane 1). B) Partial sequence chromatogram of the cDNA amplified fragment showing the junction position of the PHF1 and TFE3 genes (arrow). C) Amplification of genomic PHF1-TFE3 fragments using the primer combinations PHF1Intr11-F2/TFE3-Intr7-R2 (lane 1) and PHF1-Intr11-F3/TFE3-Intr7-R3 (lane 2). M, 1 Kb DNA ladder (GeneRuler, ThermoFisher Scientific). D) The predicted PHF1-TFE3 fusion protein. The tudor domain is in lilac, the two PHD finger domains are in green, the helix-loop-helix domain is in yellow, the domain of unknown function is in brown, and the PHF1-TFE junction is in red.

respectively $(33,34)$. In all the above-mentioned fusions, the entire PHF1 coding region became the 3 ' terminal part of the fusion gene.

The TFE3 gene encodes a basic helix-loop-helix domaincontaining transcription factor that binds MUE3-type E-box sequences in the promoter of genes and activates transcription $(35,36)$. The TFE3 gene was first reported as a neoplasia-associated fusion partner in papillary renal cell carcinomas carrying a $\mathrm{t}(\mathrm{X} ; 1)(\mathrm{p} 11.2 ; \mathrm{q} 21.2)$ chromosome translocation which fused PRCC to TFE3 $(37,38)$. Since then, TFE3 was found to be a partner in more than 10 different fusion genes in various neoplasms amongst which are $N O N O, S F P Q$, and $D V L 2$ in papillary renal cell carcinomas and PEComas (39-41), ASPSCR1 in alveolar soft part sarcoma and papillary renal cell carcinomas $(42,43)$, and YAPI in epithelioid hemangioendothelioma (44). 
Oncogenic activity of some TFE3 gene fusions has been shown in cancer models. The PRCC-TFE3 and SFPQ-TFE3 fusions transformed NIH3T3 mouse fibroblast cells $(45,46)$ and the alveolar soft part sarcoma-associated fusion ASPSCR1-TFE3 was shown to drive tumorigenesis in mice $(47,48)$. The widely accepted model for oncogenic activity of TFE3 gene fusions is that the 5'-partner gene has a stronger or less tightly controlled promoter than TFE3, one that is not regulated in the same manner as the wild-type TFE3 promoter (49). Thus, in the fusion proteins, the basic helix-loop-helix domain and the carboxyl terminal part of TFE3 are upregulated (49). Consistent with this model, all TFE3 fusion partners have constitutively active gene promoters leading TFE3 fusion proteins to be expressed at dramatically higher levels than wild-type TFE3 (49).

Based on the reference sequences NM_002636.4/NP_00 2627.1 for PHF1 and NM_006521.5/NP_006512.2 for TFE3, the fusion $P H F 1-T F E 3$ we describe is predicted to code for a 636 amino acid residues chimeric transcription factor consisting of the first 395 and the last 241 (position 335-575) amino acid residues of the PHF1 and TFE3 proteins, respectively (Figure 3D). The PHF1-TFE3 protein contains the tudor domain and the two PHD zinc finger domains of PHF1, and the helix-loop-helix domain and a carboxyl domain of unknown function of TFE3 $(22,36)$. The expression of the helix-loop-helix domain and the carboxyl domain of TFE3 is therefore regulated by the $P H F 1$ promoter.

Although the tumor cells of the malignant chondroid syringoma carried a simple $t(X ; 6)(p 11 ; p 21)$ translocation, we believe that additional submicroscopic rearrangements took place that facilitated formation of the PHF1-TFE3 fusion gene. At the genomic level, PHFl (on chromosome band $6 \mathrm{p} 21)$ is transcribed from telomere to centromere whereas transcription of TFE3 (on chromosome band Xp11) proceeds in the opposite direction, from centromere to telomere. Hence, formation of a PHF1-TFE3 fusion is not possible through a simple $\mathrm{t}(\mathrm{X} ; 6)(\mathrm{p} 11 ; \mathrm{p} 21)$ alone but would require an additional genomic aberration, such as inversion, on one of the derivative chromosomes, $\operatorname{der}(\mathrm{X})$ or $\operatorname{der}(6)$.

Hallor et al. (14) reported a case of myoepithelioma/ mixed tumor with der(6)ins $(6 ; \mathrm{X})(\mathrm{p} 21 ; \mathrm{p} 11 \mathrm{p} 22)$ among several other aberrations and another case in which del $(\mathrm{X})(\mathrm{p} 11)$ was part of a complex karyotype. In another study reporting recurrent $P H F 1$ rearrangements in ossifying fibromyxoid tumors, two of the cytogenetically analyzed cases had karyotypes in which chromosome bands Xp11 and 6p21 had also been targeted (17). The first tumor had the karyotype $46, Y$, ins $(X ; 6)(p 11 ; p 21 p 25), t(2 ; 12)(q 31 ; q 22),+12$ whereas the second tumor had the more complex karyotype $45, \mathrm{Y}, \operatorname{add}(\mathrm{X})$ (p11),del(1)(p35),der(3)t(3;16)(p12;p11), der(6) t(6;7)(p21; $\mathrm{p} 15), \operatorname{der}(7) \mathrm{t}(\mathrm{X} ; 7)(\mathrm{p} 2 ? ; \mathrm{p} 15) \mathrm{t}(\mathrm{X} ; 6)(\mathrm{p} 11 ; \mathrm{p} 21), \operatorname{del}(13)(\mathrm{q} ? 21)$, $\operatorname{der}(17) \mathrm{t}(? 13 ; 17)(\mathrm{q} 2 ? 2 ; \mathrm{q} 2 ? 5),-20$. Both tumors had PHF1 rearrangements but did not have the EP400-PHF1 fusion.
Based on the transcription orientation of the PHF1 and TFE3 genes, the involvement of chromosome bands Xp11 and 6 p21 as visualized by karyotyping, the aberration of PHF1 in ossifying fibromyxoid tumors (17) and the fact that the cases reported by Hallor et al. (14) were myoepithelioma/ mixed tumors (14), it is likely that the above-mentioned tumors carried a PHF1-TFE3 fusion gene.

The present study shows that malignant chondroid syringoma on the one hand is genetically related to tumors with PHF 1 rearrangements such as low-grade endometrial sarcoma and ossifying fibromyxoid tumor, and on the other hand to tumors carrying TFE3 rearrangements such as renal cell carcinoma, alveolar soft part sarcoma, PEComa, and epithelioid hemangioendothelioma. Further investigations of malignant chondroid syringomas and myoepithelial tumors are needed in order to determine the frequency of $P H F 1$ TFE3 and, in particular, to find out what kind of genetic heterogeneity exists.

\section{Conflicts of Interest}

The Authors declare that they have no potential conflicts of interest exist.

\section{Authors' Contributions}

IP performed experiments, was the primary Author of the manuscript, produced experimental design, performed the bioinformatics analysis, conceived the study, and drafted the manuscript. LG performed cytogenetic analysis, ML-I performed the pathological examination, $\mathrm{AB}$ performed the pathological examination, $\mathrm{SH}$ assisted with experimental design and writing of the manuscript. All Authors read and approved the final manuscript.

\section{Acknowledgements}

This work was supported by grants from Radiumhospitalets Legater.

\section{References}

1 Chauvel-Picard J, Pierrefeu A, Harou O, Breton P and Sigaux N: Unusual cystic lesion of the eyebrow: A case report of malignant chondroid syringoma. J Stomatol Oral Maxillofac Surg 119: 232235, 2018. PMID: 29477759. DOI: 10.1016/j.jormas. 2018. 02.008

2 Ahn CS and Sangueza OP: Malignant sweat gland tumors. Hematol Oncol Clin North Am 33: 53-71, 2019. PMID: 30497677. DOI: 10.1016/j.hoc.2018.09.002

3 Lal K, Morrell TJ, Cunningham M, O'Donnell P, Levin NA and Cornejo KM: A case of a malignant cutaneous mixed tumor (chondroid syringoma) of the scapula treated with staged margincontrolled excision. Am J Dermatopathol 40: 679-681, 2018. PMID: 29533281. DOI: 10.1097/DAD .0000000000001131

4 Tural D, Selcukbiricik F, Gunver F, Karismaz A and Serdengecti S: Facial localization of malignant chondroid syringoma: a rare case report. Case Rep Oncol Med 2013: 907980, 2013. PMID: 23476847. DOI: $10.1155 / 2013 / 907980$ 
5 Hornick JL and Fletcher CD: Cutaneous myoepithelioma: a clinicopathologic and immunohistochemical study of 14 cases. Hum Pathol 35: 14-24, 2004. PMID: 14745720.

6 Jo VY and Fletcher CD: Myoepithelial neoplasms of soft tissue: an updated review of the clinicopathologic, immunophenotypic, and genetic features. Head Neck Pathol 9: 32-38, 2015. PMID: 25804378. DOI: $10.1007 / \mathrm{s} 12105-015-0618-0$

7 Jo VY: Myoepithelial Tumors: An Update. Surg Pathol Clin 8: 445466, 2015. PMID: 26297065. DOI: 10.1016/j.path.2015. 05.005

8 Kutzner H, Mentzel T, Kaddu S, Soares LM, Sangueza OP and Requena L: Cutaneous myoepithelioma: an under-recognized cutaneous neoplasm composed of myoepithelial cells. Am J Surg Pathol 25: 348-355, 2001. PMID: 11224605.

9 Mentzel T, Requena L, Kaddu S, Soares de Aleida LM, Sangueza OP and Kutzner H: Cutaneous myoepithelial neoplasms: clinicopathologic and immunohistochemical study of 20 cases suggesting a continuous spectrum ranging from benign mixed tumor of the skin to cutaneous myoepithelioma and myoepithelial carcinoma. J Cutan Pathol 30: 294-302, 2003. PMID: 12753168.

10 Antonescu CR, Zhang L, Chang NE, Pawel BR, Travis W, Katabi N, Edelman M, Rosenberg AE, Nielsen GP, Dal Cin P and Fletcher CD: EWSR1-POU5F1 fusion in soft tissue myoepithelial tumors. A molecular analysis of sixty-six cases, including soft tissue, bone, and visceral lesions, showing common involvement of the EWSR1 gene. Genes Chromosomes Cancer 49: 1114-1124, 2010. PMID: 20815032. DOI: 10.1002/ gcc.20819

11 Bahrami A, Dalton JD, Krane JF and Fletcher CD: A subset of cutaneous and soft tissue mixed tumors are genetically linked to their salivary gland counterpart. Genes Chromosomes Cancer 51: 140-148, 2012. PMID: 22038920. DOI: 10.1002/gcc.20938

12 Brandal P, Panagopoulos I, Bjerkehagen B, Gorunova L, Skjeldal S, Micci F and Heim S: Detection of a $\mathrm{t}(1 ; 22)(\mathrm{q} 23 ; \mathrm{q} 12)$ translocation leading to an EWSR1-PBX1 fusion gene in a myoepithelioma. Genes Chromosomes Cancer 47: 558-564, 2008. PMID: 18383210. DOI: $10.1002 / \mathrm{gcc} .20559$

13 Brandal P, Panagopoulos I, Bjerkehagen B and Heim S: $\mathrm{t}(19 ; 22)(\mathrm{q} 13 ; \mathrm{q} 12)$ Translocation leading to the novel fusion gene EWSR1-ZNF444 in soft tissue myoepithelial carcinoma. Genes Chromosomes Cancer 48: 1051-1056, 2009. PMID: 19760602. DOI: $10.1002 / \mathrm{gcc} .20706$

14 Hallor KH, Teixeira MR, Fletcher CD, Bizarro S, Staaf J, Domanski HA, von Steyern FV, Panagopoulos I, Mandahl N and Mertens F: Heterogeneous genetic profiles in soft tissue myoepitheliomas. Mod Pathol 21: 1311-1319, 2008. PMID: 18604193. DOI: $10.1038 /$ modpathol.2008.124

15 Agaram NP, Chen HW, Zhang L, Sung YS, Panicek D, Healey JH, Nielsen GP, Fletcher CD and Antonescu CR: EWSR1-PBX3: a novel gene fusion in myoepithelial tumors. Genes Chromosomes Cancer 54: 63-71, 2015. PMID: 25231231. DOI: 10.1002/gcc. 22216

16 Zou Y and Billings SD: Myxoid cutaneous tumors: a review. J Cutan Pathol 43: 903-918, 2016. PMID: 27252031. DOI: 10.1111/cup.12749

17 Gebre-Medhin S, Nord KH, Moller E, Mandahl N, Magnusson L, Nilsson J, Jo VY, Vult von Steyern F, Brosjo O, Larsson O, Domanski HA, Sciot R, Debiec-Rychter M, Fletcher CD and Mertens F: Recurrent rearrangement of the PHF1 gene in ossifying fibromyxoid tumors. Am J Pathol 181: 1069-1077, 2012. PMID: 22796436. DOI: 10.1016/j.ajpath.2012.05.030
18 Endo M, Kohashi K, Yamamoto H, Ishii T, Yoshida T, Matsunobu $\mathrm{T}$, Iwamoto $\mathrm{Y}$ and Oda $\mathrm{Y}$ : Ossifying fibromyxoid tumor presenting EP400-PHF1 fusion gene. Hum Pathol 44: 2603-2608, 2013. PMID: 23806526. DOI: 10.1016/j.humpath. 2013.04.003

19 Panagopoulos I, Gorunova L, Lund-Iversen M, Andersen K, Andersen HK, Lobmaier I, Bjerkehagen B and Heim S: Cytogenetics of spindle cell/pleomorphic lipomas: Karyotyping and FISH analysis of 31 tumors. Cancer Genomics Proteomics 15: 193-200, 2018. PMID: 29695401. DOI: 10.21873/cgp.20077

20 Kangaspeska S, Hultsch S, Edgren H, Nicorici D, Murumagi A and Kallioniemi O: Reanalysis of RNA-sequencing data reveals several additional fusion genes with multiple isoforms. PLoS One 7: e48745, 2012. PMID: 23119097. DOI: 10.1371/journal. pone. 0048745

21 Nicorici D, Satalan H, Edgren H, Kangaspeska S, Murumagi A, Kallioniemi O, Virtanen S and Kikku O: FusionCatcher - a tool for finding somatic fusion genes in paired-end RNA-sequencing data. bioRxiv, 2014. DOI: 10.1101/011650

22 Coulson M, Robert S, Eyre HJ and Saint R: The identification and localization of a human gene with sequence similarity to Polycomblike of Drosophila melanogaster. Genomics 48: 381383, 1998. PMID: 9545646. DOI: 10.1006/geno.1997.5201

23 Cao R, Wang H, He J, Erdjument-Bromage H, Tempst P and Zhang Y: Role of hPHF1 in H3K27 methylation and Hox gene silencing. Mol Cell Biol 28: 1862-1872, 2008. PMID: 18086877. DOI: 10.1128/MCB.01589-07

24 Sarma K, Margueron R, Ivanov A, Pirrotta V and Reinberg D: Ezh2 requires PHF1 to efficiently catalyze H3 lysine 27 trimethylation in vivo. Mol Cell Biol 28: 2718-2731, 2008. PMID: 18285464. DOI: 10.1128/MCB.02017-07

25 Hong Z, Jiang J, Lan L, Nakajima S, Kanno S, Koseki H and Yasui A: A polycomb group protein, PHF1, is involved in the response to DNA double-strand breaks in human cell. Nucleic Acids Res 36: 2939-2947, 2008. PMID: 18385154. DOI: 10.1093/nar/gkn146

26 Liu R, Gao J, Yang Y, Qiu R, Zheng Y, Huang W, Zeng Y, Hou Y, Wang S, Leng S, Feng D, Yu W, Sun G, Shi H, Teng X and Wang Y: PHD finger protein 1 (PHF1) is a novel reader for histone H4R3 symmetric dimethylation and coordinates with PRMT5-WDR77/CRL4B complex to promote tumorigenesis. Nucleic Acids Res 46: 6608-6626, 2018. PMID: 29846670. DOI: 10.1093/nar/gky461

27 Micci F, Panagopoulos I, Bjerkehagen B and Heim S: Consistent rearrangement of chromosomal band $6 \mathrm{p} 21$ with generation of fusion genes JAZF1/PHF1 and EPC1/PHF1 in endometrial stromal sarcoma. Cancer Res 66: 107-112, 2006. PMID: 16397222. DOI: 10.1158/0008-5472.CAN-05-2485

28 Panagopoulos I, Micci F, Thorsen J, Gorunova L, Eibak AM, Bjerkehagen B, Davidson B and Heim S: Novel fusion of MYST/Esal-associated factor 6 and PHF1 in endometrial stromal sarcoma. PLoS One 7: e39354, 2012. PMID: 22761769. DOI: 10.1371/journal.pone.0039354

29 Micci F, Gorunova L, Gatius S, Matias-Guiu X, Davidson B, Heim S and Panagopoulos I: MEAF6/PHF1 is a recurrent gene fusion in endometrial stromal sarcoma. Cancer Lett 347: 75-78, 2014. PMID: 24530230. DOI: 10.1016/j.canlet.2014.01.030

30 Micci F, Brunetti M, Dal Cin P, Nucci MR, Gorunova L, Heim $\mathrm{S}$ and Panagopoulos I: Fusion of the genes BRD 8 and PHF1 in endometrial stromal sarcoma. Genes Chromosomes Cancer 56: 841-845, 2017. PMID: 28758277. DOI: $10.1002 /$ gcc.22485 
31 Brunetti M, Gorunova L, Davidson B, Heim S, Panagopoulos I and Micci F: Identification of an EPC2-PHF1 fusion transcript in low-grade endometrial stromal sarcoma. Oncotarget 9: 1920319208, 2018. PMID: 29721194. DOI: 10.18632/oncotarget. 24969

32 Antonescu CR, Sung YS, Chen CL, Zhang L, Chen HW, Singer S, Agaram NP, Sboner A and Fletcher CD: Novel ZC3H7B-BCOR, $M E A F 6-P H F 1$, and $E P C 1-P H F 1$ fusions in ossifying fibromyxoid tumors--molecular characterization shows genetic overlap with endometrial stromal sarcoma. Genes Chromosomes Cancer 53: 183-193, 2014. PMID: 24285434. DOI: 10.1002/gcc. 22132

33 Schoolmeester JK, Sukov WR, Maleszewski JJ, Bedroske PP, Folpe AL and Hodge JC: JAZF1 rearrangement in a mesenchymal tumor of nonendometrial stromal origin: report of an unusual ossifying sarcoma of the heart demonstrating JAZF1/PHF1 fusion. Am J Surg Pathol 37: 938-942, 2013. PMID: 23629446. DOI: 10.1097/PAS.0b013e318282da9d

34 Hofvander J, Tayebwa J, Nilsson J, Magnusson L, Brosjö O, Larsson O, von Steyern FV, Domanski HA, Mandahl N and Mertens F: RNA sequencing of sarcomas with simple karyotypes: identification and enrichment of fusion transcripts. Lab Invest 95: 603-609, 2015. PMID: 25867764. DOI: 10.1038/ labinvest.2015.50

35 Beckmann $\mathrm{H}$ and Kadesch T: The leucine zipper of TFE3 dictates helix-loop-helix dimerization specificity. Genes Dev 5: 1057-1066, 1991. PMID: 2044953.

36 Beckmann H, Su LK and Kadesch T: TFE3: a helix-loop-helix protein that activates transcription through the immunoglobulin enhancer muE3 motif. Genes Dev 4: 167-179, 1990. PMID: 2338243.

37 Sidhar SK, Clark J, Gill S, Hamoudi R, Crew AJ, Gwilliam R, Ross M, Linehan WM, Birdsall S, Shipley J and Cooper CS: The $\mathrm{t}(\mathrm{X} ; 1)(\mathrm{p} 11.2 ; \mathrm{q} 21.2)$ translocation in papillary renal cell carcinoma fuses a novel gene PRCC to the TFE3 transcription factor gene. Hum Mol Genet 5: 1333-1338, 1996. PMID: 8872474.

38 Weterman MA, Wilbrink M and Geurts van Kessel A: Fusion of the transcription factor TFE3 gene to a novel gene, PRCC, in $\mathrm{t}(\mathrm{X} ; 1)(\mathrm{p} 11 ; \mathrm{q} 21)$-positive papillary renal cell carcinomas. Proc Natl Acad Sci USA 93: 15294-15298, 1996. PMID: 8986805.

39 Agaram NP, Sung YS, Zhang L, Chen CL, Chen HW, Singer S, Dickson MA, Berger MF and Antonescu CR: Dichotomy of genetic abnormalities in PEComas with therapeutic implications. Am J Surg Pathol 39: 813-825, 2015. PMID: 25651471. DOI: 10.1097/PAS.0000000000000389

40 Argani P, Zhong M, Reuter VE, Fallon JT, Epstein JI, Netto GJ and Antonescu CR: TFE3-fusion variant analysis defines specific clinicopathologic associations among Xp11 translocation cancers. Am J Surg Pathol 40: 723-737, 2016. PMID: 26975036. DOI: 10.1097/PAS.0000000000000631

41 Clark J, Lu YJ, Sidhar SK, Parker C, Gill S, Smedley D, Hamoudi R, Linehan WM, Shipley J and Cooper CS: Fusion of splicing factor genes $P S F$ and NonO (p54nrb) to the TFE3 gene in papillary renal cell carcinoma. Oncogene 15: 2233-2239, 1997. PMID: 9393982. DOI: 10.1038/sj.onc.1201394
42 Argani P, Antonescu CR, Illei PB, Lui MY, Timmons CF, Newbury R, Reuter VE, Garvin AJ, Perez-Atayde AR, Fletcher JA, Beckwith JB, Bridge JA and Ladanyi M: Primary renal neoplasms with the ASPL-TFE3 gene fusion of alveolar soft part sarcoma: a distinctive tumor entity previously included among renal cell carcinomas of children and adolescents. Am J Pathol 159: 179-192, 2001. PMID: 11438465. DOI: 10.1016/S00029440(10)61684-7

43 Ladanyi M, Lui MY, Antonescu CR, Krause-Boehm A, Meindl A, Argani P, Healey JH, Ueda T, Yoshikawa H, Meloni-Ehrig A, Sorensen PH, Mertens F, Mandahl N, van den Berghe H, Sciot $\mathrm{R}$, Dal Cin $\mathrm{P}$ and Bridge J: The $\operatorname{der}(17) \mathrm{t}(\mathrm{X} ; 17)(\mathrm{p} 11 ; \mathrm{q} 25)$ of human alveolar soft part sarcoma fuses the TFE3 transcription factor gene to $A S P L$, a novel gene at $17 \mathrm{q} 25$. Oncogene 20: 4857, 2001. PMID: 11244503. DOI: 10.1038/sj.onc.1204074

44 Antonescu CR, Le Loarer F, Mosquera JM, Sboner A, Zhang L, Chen CL, Chen HW, Pathan N, Krausz T, Dickson BC, Weinreb I, Rubin MA, Hameed M and Fletcher CD: Novel YAP1-TFE3 fusion defines a distinct subset of epithelioid hemangioendothelioma. Genes Chromosomes Cancer 52: 775-784, 2013. PMID: 23737213. DOI: $10.1002 / \mathrm{gcc} .22073$

45 Weterman MA, van Groningen JJ, den Hartog A and Geurts van Kessel A: Transformation capacities of the papillary renal cell carcinoma-associated PRCCTFE3 and TFE3PRCC fusion genes. Oncogene 20: 1414-1424, 2001. PMID: 11313885. DOI: 10.1038/sj.onc. 1204213

46 Mathur M and Samuels HH: Role of PSF-TFE3 oncoprotein in the development of papillary renal cell carcinomas. Oncogene 26: 277283, 2007. PMID: 16832349. DOI: 10.1038/ sj.onc.1209783

47 Goodwin ML, Jin H, Straessler K, Smith-Fry K, Zhu JF, Monument MJ, Grossmann A, Randall RL, Capecchi MR and Jones KB: Modeling alveolar soft part sarcomagenesis in the mouse: a role for lactate in the tumor microenvironment. Cancer Cell 26: 851-862, 2014. PMID: 25453902. DOI: 10.1016/j.ccell. 2014.10.003

48 Tanaka M, Homme M, Yamazaki Y, Shimizu R, Takazawa Y and Nakamura T: Modeling Alveolar Soft Part Sarcoma Unveils Novel Mechanisms of Metastasis. Cancer Res 77: 897-907, 2017. PMID: 27979841. DOI: 10.1158/0008-5472.CAN-16-2486

49 Kauffman EC, Ricketts CJ, Rais-Bahrami S, Yang Y, Merino MJ, Bottaro DP, Srinivasan R and Linehan WM: Molecular genetics and cellular features of TFE3 and TFEB fusion kidney cancers. Nat Rev Urol 11: 465-475, 2014. PMID: 25048860. DOI: 10.1038 /nrurol.2014.162
Received April 9, 2019

Revised June 3, 2019

Accepted June 4, 2019 